\title{
Review Article \\ Central Role of Gimap5 in Maintaining Peripheral Tolerance and T Cell Homeostasis in the Gut
}

\author{
Mehari Endale, ${ }^{1}$ H. Ibrahim Aksoylar, ${ }^{2}$ and Kasper Hoebe ${ }^{1}$ \\ ${ }^{1}$ Department of Molecular and Cellular Immunology, Cincinnati Children's Hospital Research Foundation, MLC7021, \\ Room S5.421, 3333 Burnet Avenue, Cincinnati, OH 45229-3039, USA \\ ${ }^{2}$ Department of Genetics and Complex Diseases, Harvard School of Public Health, Boston, MA 02115, USA \\ Correspondence should be addressed to Kasper Hoebe; kasper.hoebe@cchmc.org
}

Received 29 July 2014; Accepted 15 September 2014

Academic Editor: H. Barbaros Oral

Copyright (C) 2015 Mehari Endale et al. This is an open access article distributed under the Creative Commons Attribution License, which permits unrestricted use, distribution, and reproduction in any medium, provided the original work is properly cited.

\begin{abstract}
Inflammatory bowel disease (IBD) including Crohn's disease and ulcerative colitis is often precipitated by an abnormal immune response to microbiota due to host genetic aberrancies. Recent studies highlight the importance of the host genome and microflora interactions in the pathogenesis of mucosal inflammation including IBD. Specifically, genome-wide (GWAS) and also nextgeneration sequencing (NGS) - including whole exome or genome sequencing-have uncovered a large number of susceptibility loci that predispose to autoimmune diseases and/or the two phenotypes of IBD. In addition, the generation of "IBD-prone" animal models using both reverse and forward genetic approaches has not only helped confirm the identification of susceptibility loci but also shed critical insight into the underlying molecular and cellular pathways that drive colitis development. In this review, we summarize recent findings derived from studies involving a novel early-onset model of colitis as it develops in GTPase of immunityassociated protein 5- (Gimap5-) deficient mice. In humans, GIMAP5 has been associated with autoimmune diseases although its function is poorly defined. Here, we discuss how defects in Gimap5 function impair immunological tolerance and lymphocyte survival and ultimately drive the development of $\mathrm{CD} 4^{+} \mathrm{T}$ cell-mediated early-onset colitis.
\end{abstract}

\section{Introduction}

The gastrointestinal tract is endowed with a complex immune network that has a major interface with the external environment and thus presents a site with a significant immunological challenge to maintain homeostasis. The maintenance of immune tolerance and gut homeostasis is achieved by an integrated regulation of innate and adaptive immunity but also involves the microbiome itself. The dysregulation of one of these biological components or a combination thereof often precipitates intestinal inflammation or IBD. In general, IBD encompasses two major chronic relapsing inflammatory conditions in the gastrointestinal tract: ulcerative colitis (UC) and Crohn's disease (CD). UC typically involves bloody diarrhea and inflammation involving the rectum that is often extended towards the proximal colon. Infiltration of inflammatory cells is chronic and restricted to the superficial layers of the colonic mucosa. On the other hand, $C D$ is more pleomorphic and is characterized pathologically by discontinuous segments of transmural inflammation that can affect all parts of the GI tract, most commonly the ileocecal region. CD is often presented with development of fistulae and/or strictures while histological granulomata are a key feature. Importantly, the etiology or how dysregulation of the biological components required for gut homeostasis contributes to UC and CD remains poorly defined. An indepth understanding in the development and/or causes of IBD will require a critical understanding of the interplay between several factors, including genetic susceptibility loci, the host immune system function, the development and composition of the intestinal microflora, and environmental factors such as diet, antibiotic treatment, appendectomy, and hygiene status [1-3]

Recent technical advances that allow for whole genome/ exome sequencing $[4,5]$ and large scale genome wide association studies (GWAS) $[6,7]$ have led to a dramatic expansion of genetic studies and significantly advanced our understanding of the importance of susceptibility loci 
associated with chronic (auto-)immune diseases including IBD [4-9]. Not only have NGS approaches been used to identify new and rare variants causing IBD using whole genome and/or whole exome sequencing, but also they have been used to facilitate transcriptome profiling in tissues from IBD patients (RNAseq analysis) and perform epigenomic characterization using CHIP-seq technology. In addition, next-generation sequencing allows for an in-depth analysis of the intestinal microbiome through $16 \mathrm{~S}$ rRNA sequencing and thus promises to identify the role of microflora in IBD development. To date, more than 160 IBD genes and/or loci have been identified by GWAS $[10,11]$, most of them contributing modestly (relative risk of $<2$-fold) to disease susceptibility [12]. The identified loci predominantly represent polymorphisms in genes involved in the innate and/or adaptive immune function [13-15] but also involve genes required for autophagy $[16,17]$, epithelial barrier function [18], and/or activation of the endoplasmic reticulum stress response [19], indicating the diverse etiology of IBD [13, 20, 21]. The biological consequences and establishment of causality for associated variants still remain a challenging endeavor that relies on in-depth prior knowledge of gene function $[22,23]$. As a consequence, for a large number of IBD loci, the functional alleles have not been confirmed and often the causal gene itself is unclear. Thus, the identification of causative genes and alleles remains a significant challenge. Nonetheless, traits that currently have been confirmed as susceptibility genes for IBD and are subject of intense research efforts include NOD2 [20], HLA class II [24], IL23R [14], and genes involved in autophagy (e.g., Leucine-rich repeat kinase 2 [LRRK2] [25], ATG16L1 [16], and immunity related guanosine triphosphate $M[I R G M]$ ) [17]. For some, gene function is well defined [26, 27]; however, the functional implications of gene variants and how they predispose to colitis often remain elusive $[8,28,29]$. Whereas CD and UC behave as polygenic traits, rare cases of early-onset severe IBD presenting in infancy mostly behave as Mendelian disorders resulting from autosomal recessive mutations in single genes [30-34]. Mutations in IL10RA, IL10RB [35], or X-linked inhibitor of apoptosis (XIAP) [36] that cause severe forms of CD in infants born to consanguineous parents are prime examples [37]. Unfortunately, because of the disease severity often seen in early-onset IBD and the low frequency of patients carrying (unique) variants that may be life-threatening, identification of the genetic cause has often proved to be challenging. Current strategies involve resequencing of candidate genes and/or sequencing the whole genome/exome of individual patients by next-generation sequencing. While NGS has the potential to unveil all genome-/exome-wide variants, the understanding of the biological consequences of such variants again is challenging and requires a priori knowledge of gene function [22].

The use of (genetic) animal models has been helpful in providing biological insights into how genetic susceptibility loci affect gut homeostasis and, for instance, has revealed critical immunological pathways that are required for immunological tolerance in the gut [22, 38, 39]. Moreover, such models have revealed insight into the intricate balance between (altered) immune function and the role of microflora to IBD development [40]. To this extent, both forward and reverse genetic approaches have been valuable tools to improve our understanding of genes function, their regulation, and other complex interactions at the cellular and organismal level [22].

Our laboratory has applied an N-ethyl-N-nitrosourea (ENU) mutagenesis approach to identify genes with nonredundant function in lymphocyte development, priming, or effector function. As a result, we have identified a number of germ-line mutants that exhibit impaired peripheral tolerance, lymphocyte survival, and/or $\mathrm{T}$ cell activation [22, 41-43]. Among these, an ENU germline, designated sphinx, exhibited reduced peripheral $\mathrm{T}$ cell survival while developing spontaneous early-onset colitis development. The development of IBD-like intestinal inflammation in Gimap5-deficient mice exhibits hallmark features of IBD development in humans that include (1) a critical role for microbial flora; (2) colitis that is $\mathrm{CD}^{+} \mathrm{T}$ cell driven; and (3) a concomitant loss of immunological tolerance, exemplified by a progressive decline in regulatory $\mathrm{T}$ cells $\left(\mathrm{T}_{\text {reg }}\right)$ numbers and function. Here, we discuss these critical aspects in the context of human IBD and consider the mechanistic pathways by which loss of Gimap5 leads to a loss of immunological tolerance ultimately causing the development of early-onset and severe colitis.

\section{Gut Homeostasis, Immune Tolerance, and the Microbiome in IBD Development}

The intestine represents a potential gateway for microbial pathogens but also contains commensal flora and dietary antigens that require strict immune tolerance. It is therefore no surprise that the gut constitutes the largest lymphoid organ in the body containing an extensive network of secondary lymphoid organs, with an enormous number of leukocytes, including several lymphocyte subpopulations that are uniquely observed in the gut $[44,45]$. Upon activation, the intestinal immune system can mount a range of immune effector functions that have the potential to damage host tissue and reduce epithelial barrier function. Thus, a failure to maintain immunological tolerance against commensal flora often results in chronic intestinal inflammation [35].

The intestinal microbiota profoundly affects the immune system development under healthy conditions and thus represents an important environmental determinant of IBD development [46]. This is supported by evidence derived from human studies and studies using mouse models, as reviewed elsewhere $[9,47,48]$. For instance, (genetic) mouse models of intestinal inflammation generally do not develop disease when housed under germ-free conditions [49]. Moreover, $\mathrm{T}$ cell-mediated colitis is largely driven by bacterial antigens and fails to develop following nonspecific activation of host T cells. For example, transfer of OVA-specific $\mathrm{CD}^{+}$ $\mathrm{T}$ cells from $\mathrm{RAG}^{-2^{-/}}$OT-II transgenic mice into RAG$2^{-/-}$recipients developed colitis only when recipient mice were colonized with OVA-expressing Escherichia coli, not with control Escherichia coli $[50,51]$. This finding has led to a particular focus in understanding the role of intestinal microbiota, that is, its composition, regulation, and interaction with 
the host immune system, in the development of IBD. The gastrointestinal tract harbors more than $10^{14}$ microorganisms of $\sim 1000$ species [52, 53], mostly contained within the colon [54]. Over 90\% of these consist of Bacteroidetes (gram negative) and Firmicutes (gram positive) bacteria. Specific Bacteroides species directly regulate antimicrobial peptide expression by intestinal epithelium through activation of Toll-like receptors (TLR) expressed on Paneth cells [55]. Moreover, the presence of specific bacterial species shapes adaptive immune functions within the intestines, including Enterobacteriaceae and Bacteroidaceae [56] for TCR $\alpha \beta$ intraepithelial lymphocytes; Bacteroides fragilis [57] and a mixture of Clostridia strains [58] for T regulatory cells; and cytophaga-flavobacterium-bacteroidetes and segmented filamentous bacterium for Th17 cells [59-61]. Thus, changes in the composition of commensal microbiota-(dysbiosis) may present a critical determinant of host immune responses and thereby contribute to the development of IBD [29]. Interestingly, studies involving $16 \mathrm{~S}$ rRNA sequencing from gut biopsy or stool samples revealed a detectable difference between the intestinal microbiota in the two forms of IBD (CD and UC) compared to healthy controls [62]. However, whether the observed dysbiosis in microbiota is directly associated with the presence of IBD susceptibility loci or a consequence of intestinal inflammation per se is currently unclear and an area of intense inquiry. A prime example of bacterial species driving colitis is provided by studies involving Helicobacter hepaticus-a commensal bacterium with opportunistic pathogenic potential [57,63]. Although colonization of wild-type C57BL/6J mice with $H$. hepaticus does not result in inflammation or disease, $H$. hepaticus induces colitis in $\mathrm{IL}_{10} 0^{-/-}$[64] or SCID/Rag2 ${ }^{-/-}$hosts that received naive $\mathrm{CD}^{+} \mathrm{CD} 45 \mathrm{RB}^{\text {high }} \mathrm{T}$ cells [63]. This colitis model is driven by homeostatic proliferation of naïve $\mathrm{T}$ cells through bacterial antigens including the flagellar antigen of H. hepaticus [65]. Colitis induction in this model is only observed in the absence of $\mathrm{T}_{\text {reg }}$ cells allowing for robust $\mathrm{CD} 4^{+}$ $\mathrm{T}$ cell effector responses. Overall, these observations suggest that perturbations in gut microbiota and host immune system underlie the development of intestinal inflammation and IBD-an etiology referred to as the two-hit hypothesis [66].

\section{Monogenic Causes of IBD}

Interestingly, a large number of IBD susceptibility loci identified by GWAS studies are shared with other complex (auto)immune diseases such as type-1 diabetes, celiac disease, multiple sclerosis, and systemic lupus erythematosus [10]. This is primarily due to the fact that these loci represent genes involved in immune cell signaling, including $\mathrm{T}$ cell differentiation, immune tolerance, and/or innate immune responses $[28,67,68]$-immunological pathways that are critical determinants for (auto-)immune disease. Clear examples of such loci are loss-of-function mutations in either IL10RA or IL10RB [35]. These mutations are linked with severe, early-onset enterocolitis in children-a pathology that is also observed in mice lacking either $\operatorname{Il10}[69,70]$ or Il10rb [31, 35]. Changes in Il-10r variants are functionally linked to alterations in hematopoietic cell function and colitis can generally be cured through hematopoietic stem cell transplantation [71].

Interleukin-10 (IL-10) is a pleiotropic cytokine with a multitude of anti-inflammatory and immunoregulatory functions, which is secreted by a variety of cell types and is critical for maintaining immune homeostasis of the gut $[72,73]$. For instance, IL-10 modulates the function of APCs through inhibiting phagocytosis, downregulating the expression of MHCs and costimulatory molecules, and decreasing the production of proinflammatory cytokines and chemokines in IBD [74]. Moreover, IL-10 directly restricts the differentiation of Th cells $[70,74]$ and maintains the suppressive activity of $\mathrm{T}_{\text {reg }}$ cells [75]. Consistent with this, $\mathrm{T}$ cell-specific [76] or FoxP3 ${ }^{+} \mathrm{T}_{\text {reg }}$-specific [77] deletion of Il10 results in spontaneous colitis, highlighting the importance of $\mathrm{T}_{\text {reg }}$-derived IL-10 in preventing intestinal inflammation. On the other hand, a recent study suggests that macrophages are a prime cell target for IL-10 activity in the gut in that loss of Il-10ra specifically on macrophages resulted in spontaneous colitis development [78]. Overall, these studies establish IL-10 as a central mediator in gut homeostasis affecting both innate and adaptive immune responses.

\section{The Role of $\mathrm{CD4}^{+}$T Cells in Colitis}

The key challenge of the intestinal immune system is to properly respond to pathogens while maintaining immune tolerance towards commensal bacteria and food antigens [79] - a process that requires complex cellular and molecular regulatory mechanisms $[45,80]$. Particularly, the presence of unique immunosuppressive $\mathrm{CD}^{+} \mathrm{T}$ cell populations has been described in the intestine that control immune homeostasis and prevent inflammation towards harmless foreign antigens [81]. Importantly, increased accumulation of $\mathrm{CD} 4^{+}$ $\mathrm{T}$ cells in the intestine is a key feature of inflammatory bowel disease $[9,82]$ and presents an important therapeutic target. Intestinal $\mathrm{CD}^{+} \mathrm{T}$ cell populations can be broadly classified based on function into effector $\mathrm{CD} 4^{+} \mathrm{T}$ cells and regulatory $\mathrm{CD} 4^{+} \mathrm{T}$ cells.

Effector $\mathrm{CD}^{+} \mathrm{T}$ cells, also referred to as helper $\mathrm{T}$ (Th) cells, play a critical role in the execution of immune functions. These include the development of antigen-specific $\mathrm{CD} 8^{+} \mathrm{T}$ and $\mathrm{B}$ cell responses and inflammatory cytokine production causing the recruitment of effector cells such as neutrophils. Whereas early studies primarily focused on the functional distinction between Th1 (or IFN $-\gamma^{+}$producing $\mathrm{CD}^{+}{ }^{+} \mathrm{T}$ cells) and Th2 cells (interleukin 4-producing $\mathrm{T}$ cells), more in-depth studies in mice suggested that Th2 cells were largely absent in healthy mouse colonies in the absence of intestinal parasites [83]. Importantly, a third subset, the Th17 subset of $\mathrm{CD}^{+} \mathrm{T}$ cells, has recently been described as the major $\mathrm{T}$ cell population within both healthy and inflamed intestinal mucosa [84]. The identification of this subset has almost entirely shifted the focus on this cell type as a driver of disease in both experimental models and human IBD. Th17 cells produce a large number of cytokines, including IL-17A and IL-17F-key cytokines involved in the 
recruitment and activation of granulocytes and critical to the host response against extracellular bacteria. Importantly, microbiota-specific memory Th17 cells are far more potent in inducing colitis in recipient mice compared to Th1 cells [85]. Moreover, a correlation between IL17 levels and disease severity in human IBD patients has been observed [86] suggesting a key role for Th17 cells and cytokines in IBD. Although the classification of these $\mathrm{T}$ helper cells suggests a specific and unique cytokine production profile, the $\mathrm{CD} 4^{+} \mathrm{T}$ cells isolated from lamina propria undergoing active colitis can express both IL-17 and IFN $\gamma$, indicating the unique plasticity of Th17 cells and their ability to convert into Th1 cells [87]. Given that Th17 cells are the main $\mathrm{CD}^{+} \mathrm{T}$ cell population in the intestinal tract, this plasticity is thought to be of critical importance to adapt to changes in the local intestinal environment and mount a proper immune response while maintaining gut homeostasis.

The importance and dominance of regulatory $\mathrm{T}$ cells and their immunosuppressive function are demonstrated by the fact that the majority of individuals do not develop gut inflammation despite an enormous microbial and antigenic load within the intestine. Moreover, transfer of naïve $\mathrm{CD}^{+} \mathrm{CD}^{2} 5 \mathrm{RB}^{\text {high }} \mathrm{CD} 4^{+} \mathrm{T}$ cells in lymphopenic hosts such as Rag1/2 $2^{-/-}$or SCID mice induces lymphopenia-induced T cell activation and colitis only in the absence regulatory $\mathrm{T}$ cells (reviewed in $[45,88]$ ).

Thus, $\mathrm{T}_{\text {regs }}$ cells play a critical role in maintaining immune homeostasis and limiting autoimmune responses by modulating cells of both the innate and the adaptive immune systems. The main types of regulatory cells in the gut are the natural (thymic) and adaptive (induced) $\mathrm{CD} 4^{+} \mathrm{FoxP}^{+} \mathrm{T}_{\text {regs }}$, as well as Tr1 and Th3 cells [89]. The effector pathways by which $\mathrm{T}_{\text {regs }}$ induce tolerance are multiple and include secretion of inhibitory cytokines such as IL-10 and transforming growth factor- $\beta$ (TGF- $\beta$ ), granzyme-mediated cytolysis of target cells, expression of cytotoxic T-lymphocyte antigen(CTLA-) 4 resulting in $\mathrm{T}$ cell inhibition, and metabolic disruption $[45,90,91]$. Impaired immune regulation by $\mathrm{T}_{\text {reg }}$ cells will result in a loss of immunological tolerance in the gut and cause colitis. Such deficiencies may stem from inadequate numbers of $\mathrm{T}_{\text {reg }}$ cells-due to impaired development, proliferation, or survival-or defects in immunosuppressive function intrinsic to $\mathrm{T}_{\text {reg }}$ cells. Alternatively, pathogenic effector $\mathrm{T}$ cells may be resistant to suppression by $\mathrm{T}_{\text {reg }}$ cells. At the site of inflammation, effector $\mathrm{T}$ cells are reported to develop mechanisms of resistance to $\mathrm{T}_{\text {reg }}$ regulation $[92,93]$, although the underlying mechanisms remain poorly defined.

In humans, the critical role for $\mathrm{T}_{\text {reg }}$ cells in preventing gut inflammation is further supported by the finding that individuals with genetic abberations in IPEX causing functional impairment of the transcription factor FoxP3 develop severe bowel inflammation [94]. Moreover, patients with genetic mutations in FoxP3 who lack or have nonfunctional $\mathrm{T}_{\text {regs }}$ exhibit severe intestinal inflammation associated with lymphocytic infiltration of the intestinal mucosa $[95,96]$. Similarly, mice lacking FoxP ${ }^{+} \mathrm{T}_{\text {regs }}[92,97]$ or lacking the ability to suppress via $\mathrm{T}_{\text {reg }}$-derived cytokines such as IL-10 [45, 89], IL-35 [98], and TGF $\beta$ [99] develop severe colitis.
Together, these studies highlight the importance of CD $4^{+} \mathrm{T}$ cells, particularly $\mathrm{T}_{\text {reg }}$ cells, in maintaining gut homeostasis. In addition, they point to monogenic causes of IBD that specifically affect $\mathrm{T}_{\text {reg }}$ function ultimately leading to loss of immunological tolerance and gut inflammation.

\section{GIMAP5: A Critical Determinant of $T$ Cell Survival and Peripheral Tolerance}

Recently, studies have identified the GTPase of immunityassociated protein 5 (GIMAP5) as a key factor in maintaining T cell homeostasis and immunological tolerance. GIMAP5 is part of the family of GIMAP proteins, which are predominantly expressed in lymphocytes and regulate lymphocyte survival during development, selection, and homeostasis [100-106]. Members of this family share a GTP-binding AIG1 (avrRPT2-induced gene-1) domain, derived from an AIG1 resistant gene first described in Arabidopsis thaliana that was induced upon infection with Pseudomonas syringae type III. The AIG domain is conserved across vertebrates and angiosperms and, in vertebrates, the family consists of seven (human and rat) and eight (mouse) members that are clustered within a tight single region on chromosomes 7, 4, and 6, respectively, ([107-110] and (Figure 1)). Mouse Gimap5 is a 308-amino acid protein that contains an AIG1 domain (residues 24-227) comprising five GTP-binding motifs (G1-G5), a P-loop NTPase domain (residues 1-168), two coiled-coil domains (residues 187-221 and 239-265), and a transmembrane domain (residues 284-304) ([105, 106] and (Figure 1)). Recent crystallographic studies revealed that the Gimap proteins manifest a nucleotide coordination and dimerization mode similar to dynamin GTPase-a component essential for the scission and fusion of cellular vesicular compartments such as endosomes [111, 112]. Members of the Gimap family appear to be expressed in different subcellular compartments, with Gimap5 localizing in multivesicular bodies (MVBs) and lysosomes in lymphocytes [113]. Their function in lymphocytes, however, remains poorly defined.

Genetic aberrancies of GIMAP5 have been linked to impaired immunological tolerance, lymphocyte survival, homeostasis, and autoimmunity in a variety of species including humans, mice, and rats. In humans, polyadenylation polymorphisms in GIMAP5 are associated with increased concentrations of IA2 autoantibodies in type 1 diabetes (T1D) patients [114] and an increased risk of systemic lupus erythematosus SLE $[115,116]$. Moreover, in patients with T1D, expression of several GIMAP genes including GIMAP5 is reduced in $\mathrm{T}_{\text {reg }}$ cells compared to healthy individuals [117]. In a spontaneous rat model of type I diabetes (the BioBreeding diabetic prone (BB-DP) rats), abnormal thymocyte development and premature death of peripheral $\mathrm{CD} 4^{+}$and $\mathrm{CD} 8^{+} \mathrm{T}-$ cells $[110,118,119]$ were linked to a frame shift mutation in GIMAP5, designated lyp, causing a truncated nonfunctional protein (GIMAP5 $5^{\text {lyp/lyp }}$ ) [100-106]. In the presence of the diabetogenic MHC locus IDDM1, this lyp mutation is essential for diabetes onset in BB-DP rats ultimately triggering lethal disease $[105,106,110]$. A similar loss of lymphocyte survival is observed in Gimap5 $5^{-/-}$null mice [120]. However, the loss 


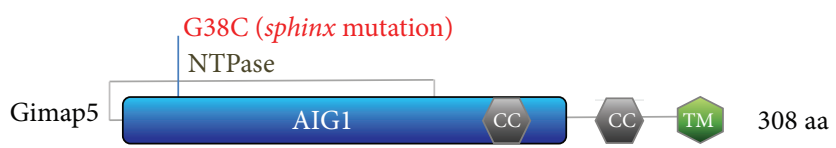

(a)
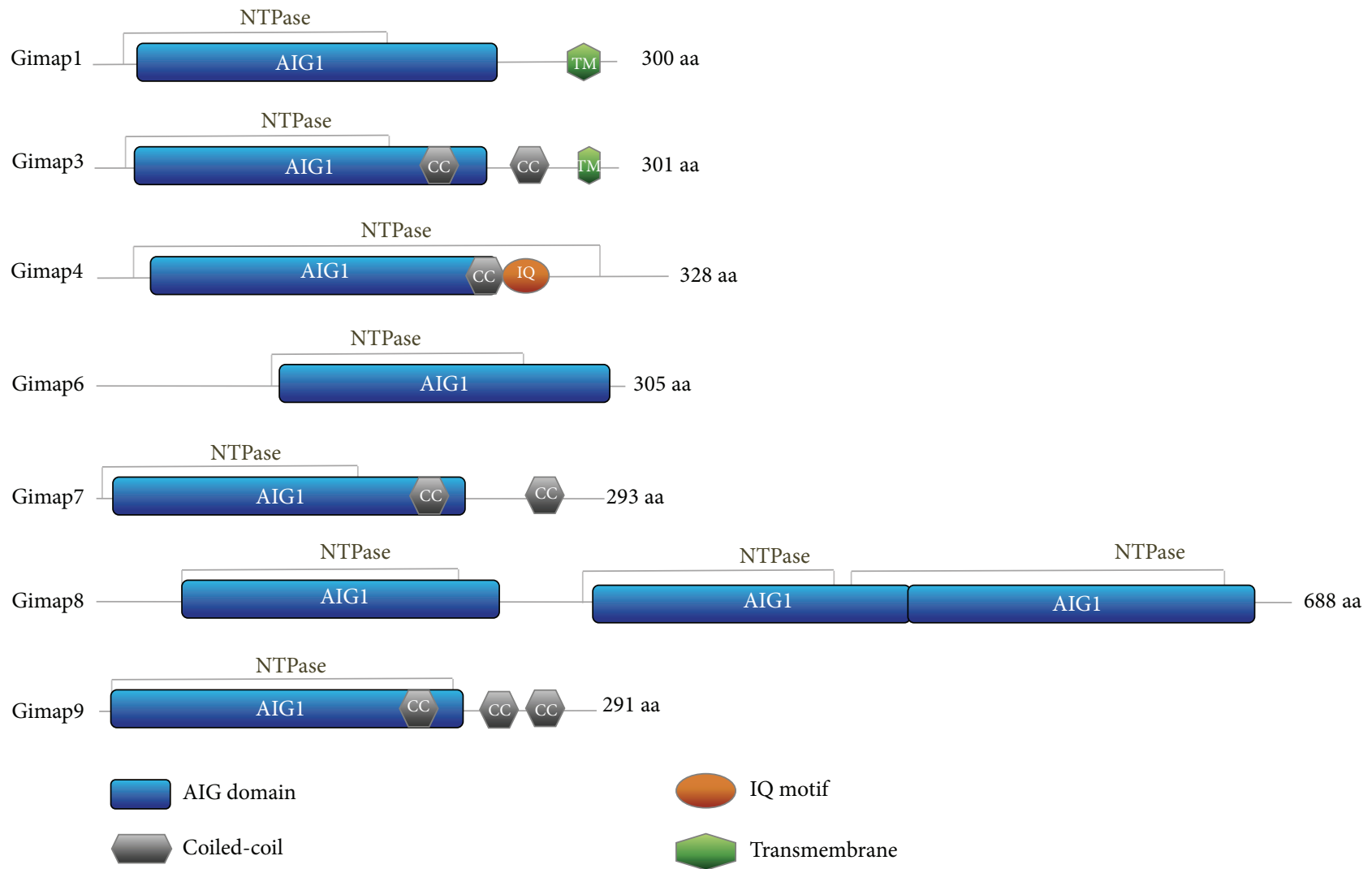

(b)

FIGURE 1: Predicted structural domains within mouse Gimap5. (a) Mouse Gimap5 is a 308-amino acid protein that contains an AIG1 domain (residues 24-227), a P-loop NTPase domain (residues 1-168), two coiled-coil domains (residues 187-221 and 239-265), and a transmembrane domain (residues 284-304). The $\mathrm{G} \rightarrow \mathrm{C}$ missense mutation in sphinx mice at residue 38 is indicated. (b) Schematic overview of the domain features present in the different Gimap family members.

of lymphocyte survival in Gimap5 $5^{-1-}$ mice is not limited to T cells, but also extends to reduced survival of NK, iNKT, and B cells with extensive extramedullary hematopoiesis observed in the liver [120].

These observations were confirmed by an N-ethyl-Nnitrosourea (ENU) induced Gimap5-germline mutant identified in our laboratory-designated sphinx. ENU is a widely used mutagen to create random germline point mutations in mice and has proven to be an effective approach to probe and identify critical genes for any phenotype of interest, for example, colitis or development/function of the immune system $[22,121]$. Phenotypes causing ENU mutations primarily involve missense mutations $(\sim 61 \%)$ or nonsense mutations (10\%) (source: http://mutagenetix.utsouthwestern.edu/), the type of genetic variants that can be found in humans. The sphinx mutation involved a $\mathrm{G} \rightarrow \mathrm{T}$ point mutation in Gimap5 resulting in a G38C substitution in the predicted GTPbinding domain of Gimap5 [42]. The mutation destabilized the protein and caused a complete loss-of-function similar to the published Gimap5 KO [26]. Specifically, the sphinx mutant exhibited a similar reduced lymphocyte survival, including loss of NK cells, $\mathrm{CD} 4^{+} \mathrm{T}, \mathrm{CD}^{+} \mathrm{T}$, and $\mathrm{B}$ cells to the Gimap5 knockout mice reported. The causative germline mutation involved a single $\mathrm{G} \rightarrow \mathrm{T}$ point mutation in Gimap5. This mutation resulted in a G38C substitution in the predicted GTP-binding domain of Gimap5, destabilizing the protein and causing a complete loss-of-function. Interestingly, from birth until weaning, sphinx (or Gimap5 $5^{\text {sph/sph }}$ ) mice appear outwardly healthy. However, after 7-8 weeks of age, mice lose weight and develop severe colitis, exemplified by goblet cell depletion, lamina propria leukocyte infiltration, epithelial cell hyperplasia, and crypt loss [42, 43]. The severe colitis likely contributed to the early mortality of Gimap5 $5^{\text {sph/sph }}$ mice, which generally occurred by 14 weeks of age. Interestingly, antibiotic treatment blocked intestinal inflammation in Gimap $5^{s p h / s p h}$ mice, suggesting a critical role 


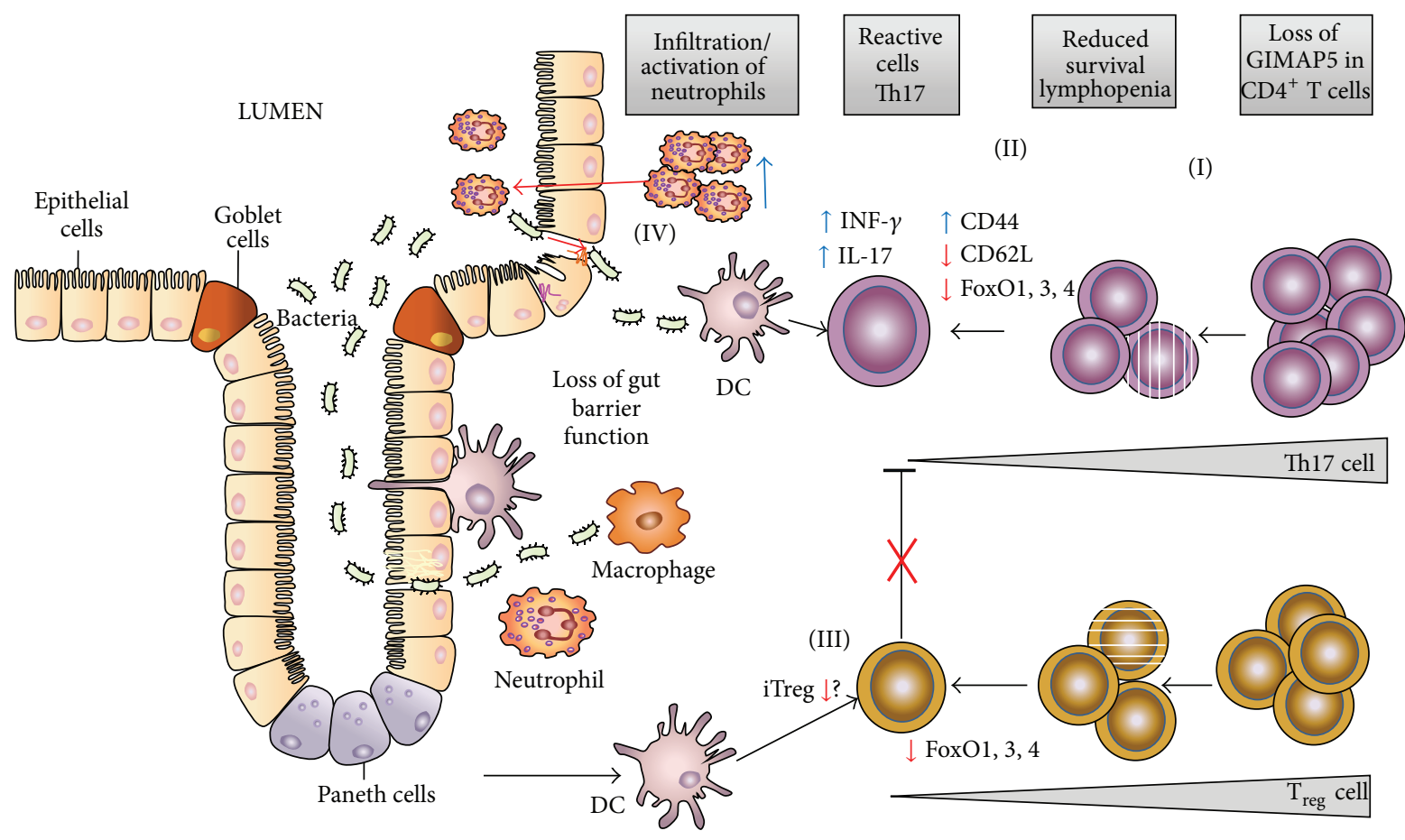

FIGURE 2: Schematic representation of the key events causing colitis in Gimap5-deficient mice. Loss of Gimap5 leads to reduced survival of lymphocytes (I) including $\mathrm{CD}^{+} \mathrm{T}$ cells with remaining $\mathrm{T}$ cells exhibiting a characteristic LIP phenotype $\left(\mathrm{CD} 44^{\text {high }}\right.$; CD62 $\left.\mathrm{L}^{\text {low }}\right)$ and polarization towards Th17 (II). Importantly, during the onset of $\mathrm{CD}^{+} \mathrm{T}$ cell lymphopenia, a progressive loss of full-length FoxO1, FoxO3, and FoxO4 expression is observed that correlates with a loss of $\mathrm{T}_{\text {reg }}$ induction (iTreg) and function in the gut tissue (III). The lack of $\mathrm{T}_{\text {reg }}$ immunosuppressive activity (indicated by the red X) triggers activation of CD4 $4^{+}$Thl/Thl7 cells in the gut causing production of IL17 and IFN $\gamma$ cytokines and subsequent infiltration of macrophages/neutrophils that further amplify intestinal inflammation and a loss of epithelial barrier function (IV) and may ultimately lead to neutrophil transepithelial migration (for an extensive review on neutrophils in IBD pathogenesis, see [133]).

for the microbiome also in this spontaneous model of colitis. Overall, inflammation of the gut in Gimap5 $5^{\text {sph/sph }}$ mice is early-onset and behaves as a monogenic trait, thus very similar to mutations in IL10RA, IL10RB, or XIAP [32, 33, 122, 123].

\section{Gimap $5^{\text {sph/sph }}$ Mice: A Novel T Cell-Mediated Colitis Model}

Gimap5 $5^{\text {sph/sph }}$ mice exhibit an absence of $\mathrm{NK}$ or $\mathrm{CD} 8^{+}$ $\mathrm{T}$ cell populations in peripheral lymphoid organs. Interestingly, relatively normal thymocyte development occurs, including $\mathrm{CD}^{+} \mathrm{T}$ cell, $\mathrm{CD}^{+} \mathrm{T}$ cell, and Foxp3 ${ }^{+}$regulatory $\mathrm{T}$ cell lineages [42]. Nonetheless, Gimap $5^{\text {sph/sph }}$ mice exhibit a progressive reduction in circulating $\mathrm{CD}^{+} \mathrm{T}$ cells and the $\mathrm{CD} 4^{+} \mathrm{T}$ cells that remain after five weeks of age exhibit a lymphopenia-induced proliferation (LIP) phenotype (CD44 ${ }^{\text {high }}$ and CD62 $\mathrm{L}^{\text {low }}$ ), a $\mathrm{T}$ cell phenotype associated with autoimmunity [124]. Interestingly, despite their reduced survival, Gimap5 $5^{\text {sph/sph }} \mathrm{CD} 4^{+} \mathrm{T}$ cells produced exceeding amounts of IFN $\gamma$ and IL-17A compared to wildtype $\mathrm{CD}^{+} \mathrm{T}$ cells and exhibited spontaneous activation in the Gimap5 $5^{s p h / s p h}$ gut tissue pointing to a potentially critical role of $\mathrm{CD}^{+}{ }^{+} \mathrm{T}$ cells in this disease model. Indeed, antibody-mediated CD4-depletion in vivo prevented colitis in these mice corroborating the importance of $\mathrm{CD} 4^{+} \mathrm{T}$ cells in the pathogenesis. The lymphopenia and expression of $\mathrm{CD} 44^{\text {high }} \mathrm{CD} 6 \mathrm{~L}^{\text {low }}$ markers by $\mathrm{CD}^{+} \mathrm{T}$ cells (Figure 2 ) are indicative of lymphopenia-induced proliferation and resemble the $\mathrm{CD}^{+}{ }^{+} \mathrm{T}$ cell phenotype first described in the adoptive transfer $\mathrm{T}$ cell model of colitis [125]. As mentioned, the development of $\mathrm{CD} 4^{+} \mathrm{T}$ cell-induced colitis in Gimap $5^{\text {sph/sph }}$ can be prevented by antibiotic-treatment, again confirming the critical role of the microbiota in $\mathrm{T}$ cell activation [43]. Although the intestinal microbiota provide a potentially large source of foreign antigens that may drive the $\mathrm{T}$ cell response towards gut tissue, it is important to note that many autoimmune diseases are associated with immunedeficiencies which result in lymphopenia and subsequent "homeostatic" proliferation. The genetic and molecular basis of how these complex processes are controlled still remains incompletely defined. $\mathrm{T}_{\text {reg }}$ cells have been implicated as a critical factor in the development of disease following homeostatic proliferation and a similar critical role for $\mathrm{T}_{\text {reg }}$ cells was observed in the colitis development in Gimap $5^{\text {sph/sph }}$ mice. Specifically, Gimap5 $5^{\text {sph/sph }}$ mice fail to maintain a $\mathrm{T}_{\text {reg }}$ population with immunosuppressive function. Whereas relatively normal numbers of Foxp $3^{+} \mathrm{T}_{\text {reg }}$ cells were found in spleen and LNs of 3-week-old mice, $\mathrm{T}_{\text {reg }}$ cell numbers were significantly reduced in 6-week old mice [43]. More 
importantly, a progressive loss of $\mathrm{T}_{\text {reg }}$ function in MLN of Gimap $5^{\text {sph/sph }}$ mice was observed. Whereas $\mathrm{T}_{\text {reg }}$ cells from 4week-old Gimap $5^{\text {sph/sph }}$ mice showed a slight but significant reduction in their ability to suppress wild-type $\mathrm{CD} 8^{+} \mathrm{T}$ cell proliferation in vitro, $\mathrm{T}_{\text {reg }}$ cells from older (6-weekold) Gimap $5^{\text {sph/sph }}$ mice were incapable of suppressing wildtype $\mathrm{CD}^{+} \mathrm{T}$ cell proliferation, suggesting a critical loss of $T_{\text {reg }}$ function and survival to be responsible for colitis development in these mice (Figure 2). Indeed, transfer of wild-type $\mathrm{CD} 4^{+} \mathrm{CD} 25^{+} \mathrm{T}_{\text {reg }}$ cells into Gimap $5^{\text {sph/sph }}$ early on prolonged survival, prevented increased $\mathrm{CD}^{+}{ }^{+} \mathrm{T}$ cell effector function in the MLN, and protected these mice from colitis [43]. Together, these data indicate that Gimap5 is a critical determinant of $\mathrm{T}_{\text {reg }}$ survival and function, thereby controlling gut homeostasis. The critical role of Gimap5 in $\mathrm{T}_{\text {reg }}$ survival/function is also evident in Type 1 diabetes in BioBreeding rats $[105,106]$ and may clarify why polyadenylation polymorphisms in GIMAP5, leading to rather subtle changes in gene expression, are associated with human autoimmune diseases such as T1D [114] and SLE [115].

\section{Molecular Determinants of Peripheral Tolerance in the Absence of Gimap5}

Given the loss of $\mathrm{T}_{\text {reg }}$ development/function, key questions currently center on understanding the molecular pathways by which Gimap5 controls $\mathrm{T}$ cell survival and peripheral tolerance. A number of studies have implicated Gimap5 to interact with $\mathrm{Bcl} 2$ members in mitochondria and implicated a critical role for Gimap5 in controlling proapoptotic pathways in T cells. Data in our laboratory, however, revealed no improved survival of lymphocytes (or prevention of colitis for that matter) when Gimap $5^{\text {sph/sph }}$ mice were crossed to Bim-deficient or Bax/Bak-deficient backgrounds (Aksoylar and Hoebe; unpublished data) suggesting that the reduced $\mathrm{T}$ cell survival is likely independent of the classical proapoptotic pathways. In terms of peripheral tolerance, a striking similarity is observed with the phenotypes reported in mice deficient in the family of Fork-head box group O (Foxo) transcription factors. The family of Foxo transcription factors contains 4 members of which three (Foxol, Foxo3, and Foxo4) have overlapping patterns of expression and transcriptional activities and they play an essential role in the quiescence and survival of $\mathrm{CD}^{+} \mathrm{T}$ cells $[126,127]$. In addition, Foxo expression has been reported to be essential for $\mathrm{T}_{\text {reg }}$ cell development and function $[128,129]$. The potential mechanisms by which Foxo transcription factors control $\mathrm{T}_{\text {reg }}$ development and function have been described in detail and include their role as coactivators downstream of the TGF $\beta$ signaling pathway by (1) interacting with SMAD proteins $[130,131]$ and by (2) directly regulating the induction of a number of $\mathrm{T}_{\text {reg }}$ cell associated genes, including Foxp3 itself but also CTLA-4 and CD25 [128, 129]. Importantly, CD4 ${ }^{+} \mathrm{T}$ cells from Gimap $5^{\text {sph/sph }}$ mice revealed a complete absence of Foxol, $-3 \mathrm{a}$, and -4 proteins. This effect was predominantly observed at the protein level with relatively normal RNA levels in $\mathrm{CD}^{+} \mathrm{T}$ cells, suggesting that regulation of Foxo3 and Foxo4 protein expression occurs predominantly at the posttranslational level. Interestingly, the loss of Foxo expression was progressive and correlated with the loss of immunological tolerance in Gimap5-deficient mice. Importantly, the loss of Foxo expression in Gimap $5^{\text {sph/sph }} \mathrm{CD}^{+} \mathrm{T}$ cells was specifically observed in cells undergoing LIP, which may suggest degradation of Foxo expression due to constitutive homeostatic activation of T cells (Figure 2). Although T cell activation in general results in a brief transient loss of Foxo expression [132], loss of Foxo expression is not observed following transfer of wild type $\mathrm{CD} 4^{+} \mathrm{T}$ cells into lymphopenic Rag2-deficient hosts (Aksoylar, Hoebe; unpublished results), suggesting that the loss of Foxo proteins in Gimap5-deficient $\mathrm{CD}^{+} \mathrm{T}$ cells involves a unique degradation mechanism. Importantly, the loss of Foxo expression in Gimap5 $5^{\text {sph } / \text { sph }}$ $\mathrm{CD}^{+} \mathrm{T}$ cells correlated with a loss of $\mathrm{T}_{\text {reg }}$ population and function and likely represents an important determinant of the colitis pathology observed in these mice.

\section{Conclusion}

A genetic alteration in Gimap5 has been strongly linked with reduced $\mathrm{T}$ cell survival and loss of immunological tolerance in both animal models and human studies. This results in predisposition to a variety of autoimmune related diseases including T1D, SLE, and colitis. Despite the profound impact of Gimap5 deficiency in terms of both lymphoid survival and peripheral tolerance, very little is understood about the molecular mechanisms underlying these robust phenotypes. Thus, a number of critical questions remain to be addressed that include (i) what is the molecular function of Gimap5 in T cells following activation?, (ii) what are the mechanistic pathways by which loss of Gimap5 causes reduced lymphocyte survival and peripheral tolerance in vivo?, and (iii) why do $\mathrm{CD} 4^{+} \mathrm{T}$ cells in Gimap5-deficient mice exhibit loss of Foxo expression at the posttranslational level?

Finally, given the severe phenotypes related to the host immune system observed in both mouse and rat Gimap5deficient models, a GIMAP5 null phenotype in humans is expected to result in a severe immunodeficiency, although the phenotype has yet to be described. Such a severe immunodeficiency would be predicted to present in infancy as a monogenic trait and, with the current sequencing capacity and efforts, de novo mutations in GIMAP5 should be considered prime causal candidates. Regardless, the detailed mechanistic insight into the loss of $\mathrm{T}$ cell survival and immunological tolerance in Gimap $5^{\text {sph/sph }}$ mice may ultimately help our understanding as to how polyadenylation polymorphisms in GIMAP5 predispose to T1D or SLE in humans. In addition, these studies point to a new candidate genetic susceptibility locus that should be taken into consideration for variants identified in early-onset colitis in pediatric patients.

\section{Conflict of Interests}

The authors declare that there is no conflict of interests regarding the publication of this paper. 


\section{Acknowledgment}

This research was funded by grants from the NIH, including NIH/NIAID RO1 Grant 1R01AI074743, NIH/NCI 1R21CA133649, PHS Grant P30 DK078392, and CCFA Grant no. 3793 .

\section{References}

[1] E. V. Loftus Jr., "Clinical epidemiology of inflammatory bowel disease: incidence, prevalence, and environmental influences," Gastroenterology, vol. 126, no. 6, pp. 1504-1517, 2004.

[2] D. Gevers, S. Kugathasan, L. A. Denson et al., "The treatmentnaive microbiome in new-onset Crohn's disease," Cell Host \& Microbe, vol. 15, no. 3, pp. 382-392, 2014.

[3] S. C. Ng, C. N. Bernstein, M. H. Vatn et al., "Geographical variability and environmental risk factors in inflammatory bowel disease," Gut, vol. 62, no. 4, pp. 630-649, 2013.

[4] M. A. Depristo, E. Banks, R. Poplin et al., "A framework for variation discovery and genotyping using next-generation DNA sequencing data," Nature Genetics, vol. 43, no. 5, pp. 491-501, 2011.

[5] J. W. Davey, P. A. Hohenlohe, P. D. Etter, J. Q. Boone, J. M. Catchen, and M. L. Blaxter, "Genome-wide genetic marker discovery and genotyping using next-generation sequencing," Nature Reviews Genetics, vol. 12, no. 7, pp. 499-510, 2011.

[6] C. S. Carlson, M. A. Eberle, L. Kruglyak, and D. A. Nickerson, "Mapping complex disease loci in whole-genome association studies," Nature, vol. 429, no. 6990, pp. 446-452, 2004.

[7] D. J. Balding, "A tutorial on statistical methods for population association studies," Nature Reviews Genetics, vol. 7, no. 10, pp. 781-791, 2006.

[8] J. Van Limbergen, D. C. Wilson, and J. Satsangi, “The genetics of Crohn's disease," Annual Review of Genomics and Human Genetics, vol. 10, pp. 89-116, 2009.

[9] A. Kaser, S. Zeissig, and R. S. Blumberg, "Inflammatory bowel disease," Annual Review of Immunology, vol. 28, no. 1, pp. 573621, 2010 .

[10] L. Jostins, S. Ripke, R. K. Weersma et al., "Host-microbe interactions have shaped the genetic architecture of inflammatory bowel disease," Nature, vol. 491, no. 7422, pp. 119-124, 2012.

[11] J. van Limbergen, G. Radford-Smith, and J. Satsangi, "Advances in IBD genetics," Nature Reviews Gastroenterology \& Hepatology, vol. 11, pp. 372-385, 2014.

[12] J. H. Cho and S. R. Brant, "Recent insights into the genetics of inflammatory bowel disease," Gastroenterology, vol. 140, no. 6, pp. 1704.e2-1712.e2, 2011.

[13] J.-P. Hugot, M. Chamaillard, H. Zouali et al., "Association of NOD2 leucine-rich repeat variants with susceptibility to Crohn's disease," Nature, vol. 411, no. 6837, pp. 599-603, 2001.

[14] R. H. Duerr, K. D. Taylor, S. R. Brant et al., "A genome-wide association study identifies IL23R as an inflammatory bowel disease gene," Science, vol. 314, no. 5804, pp. 1461-1463, 2006.

[15] A. Franke, T. Balschun, T. H. Karlsen et al., "Sequence variants in IL10, ARPC2 and multiple other loci contribute to ulcerative colitis susceptibility," Nature Genetics, vol. 40, no. 11, pp. 13191323, 2008.

[16] J. Hampe, A. Franke, P. Rosenstiel et al., "A genome-wide association scan of nonsynonymous SNPs identifies a susceptibility variant for Crohn disease in ATG16L1," Nature Genetics, vol. 39, no. 2, pp. 207-211, 2007.
[17] M. Parkes, J. C. Barrett, N. J. Prescott et al., "Sequence variants in the autophagy gene IRGM and multiple other replicating loci contribute to Crohn's disease susceptibility," Nature Genetics, vol. 39, no. 7, pp. 830-832, 2007.

[18] M. Stoll, B. Corneliussen, C. M. Costello et al., "Genetic variation in DLG5 is associated with inflammatory bowel disease," Nature Genetics, vol. 36, no. 5, pp. 476-480, 2004.

[19] A. Kaser, A.-H. Lee, A. Franke et al., "XBP1 links ER stress to intestinal inflammation and confers genetic risk for human inflammatory bowel disease," Cell, vol. 134, no. 5, pp. 743-756, 2008.

[20] Y. Ogura, D. K. Bonen, N. Inohara et al., "A frameshift mutation in NOD2 associated with susceptibility to Crohn's disease," Nature, vol. 411, no. 6837, pp. 603-606, 2001.

[21] J. Hampe, A. Cuthbert, P. J. P. Croucher et al., "Association between insertion mutation in NOD2 gene and Crohn's disease in German and British populations," The Lancet, vol. 357, no. 9272, pp. 1925-1928, 2001.

[22] K. Lampe, S. Cashman, H. Aksoylar, and K. Hoebe, "ENU mutagenesis in mice-genetic insight into impaired immunity and disease," in Mutagenesis, chapter 9, InTech, 2012.

[23] M. I. McCarthy, G. R. Abecasis, L. R. Cardon et al., "Genomewide association studies for complex traits: consensus, uncertainty and challenges," Nature Reviews Genetics, vol. 9, no. 5, pp. 356-369, 2008.

[24] P. C. F. Stokkers, P. H. Reitsma, G. N. J. Tytgat, and S. J. H. van Deventer, "HLA-DR and -DQ phenotypes in inflammatory bowel disease: A meta-analysis," Gut, vol. 45, no. 3, pp. 395-401, 1999.

[25] Z. Liu, J. Lee, S. Krummey, W. Lu, H. Cai, and M. J. Lenardo, "The kinase LRRK2 is a regulator of the transcription factor NFAT that modulates the severity of inflammatory bowel disease," Nature Immunology, vol. 12, no. 11, pp. 1063-1070, 2011.

[26] D. K. Bonen, Y. Ogura, D. L. Nicolae et al., "Crohn's diseaseassociated NOD2 variants share a signaling defect in response to lipopolysaccharide and peptidoglycan," Gastroenterology, vol. 124, no. 1, pp. 140-146, 2003.

[27] N. Inohara, Y. Ogura, A. Fontalba et al., "Host recognition of bacterial muramyl dipeptide mediated through NOD2: implications for Crohn's disease," Journal of Biological Chemistry, vol. 278, no. 8, pp. 5509-5512, 2003.

[28] P. K. Gregersen and L. M. Olsson, "Recent advances in the genetics of autoimmune disease," Annual Review of Immunology, vol. 27, pp. 363-391, 2009.

[29] J. H. Cho, "The genetics and immunopathogenesis of inflammatory bowel disease," Nature Reviews Immunology, vol. 8, no. 6, pp. 458-466, 2008.

[30] Y. Avitzur, C. Guo, L. A. Mastropaolo et al., "Mutations in tetratricopeptide repeat domain 7A result in a severe form of very early onset inflammatory bowel disease," Gastroenterology, vol. 146, no. 4, pp. 1028-1039, 2014.

[31] C. J. Moran, T. D. Walters, C.-H. Guo et al., "IL-10R polymorphisms are associated with very-early-onset ulcerative colitis," Inflammatory Bowel Diseases, vol. 19, no. 1, pp. 115-123, 2013.

[32] K. Fried and E. Vure, "A lethal autosomal recessive entero colitis of early infancy," Clinical Genetics, vol. 6, no. 3, pp. 195-196, 1974.

[33] A. Mégarbané and R. Sayad, "Early lethal autosomal recessive enterocolitis: report of a second family," Clinical Genetics, vol. 71, no. 1, pp. 89-90, 2007.

[34] H. H. Uhlig, "Monogenic diseases associated with intestinal inflammation: Implications for the understanding of inflammatory bowel disease," Gut, vol. 62, no. 12, pp. 1795-1805, 2013. 
[35] E.-O. Glocker, D. Kotlarz, K. Boztug et al., "Inflammatory bowel disease and mutations affecting the interleukin-10 receptor," The New England Journal of Medicine, vol. 361, no. 21, pp. 2033-2045, 2009.

[36] E. A. Worthey, A. N. Mayer, G. D. Syverson et al., "Making a definitive diagnosis: Successful clinical application of whole exome sequencing in a child with intractable inflammatory bowel disease," Genetics in Medicine, vol. 13, no. 3, pp. 255-262, 2011.

[37] D. L. Dinwiddie, J. M. Bracken, J. A. Bass et al., "Molecular diagnosis of infantile onset inflammatory bowel disease by exome sequencing," Genomics, vol. 102, no. 5-6, pp. 442-447, 2013.

[38] L. M. Sollid and F.-E. Johansen, "Animal models of inflammatory bowel disease at the dawn of the new genetics era," PLoS Medicine, vol. 5, no. 9, article e198, 2008.

[39] M. Saleh and C. O. Elson, "Experimental inflammatory bowel disease: insights into the host-microbiota dialog," Immunity, vol. 34, no. 3, pp. 293-302, 2011.

[40] H. Tlaskalová-Hogenová, R. Tpánková, H. Kozáková et al., “The role of gut microbiota (commensal bacteria) and the mucosal barrier in the pathogenesis of inflammatory and autoimmune diseases and cancer: contribution of germ-free and gnotobiotic animal models of human diseases," Cellular and Molecular Immunology, vol. 8, no. 2, pp. 110-120, 2011.

[41] M. J. Barnes, P. Krebs, N. Harris et al., "Commitment to the regulatory $\mathrm{t}$ cell lineage requires CARMAl in the thymus but not in the periphery," PLoS Biology, vol. 7, no. 3, p. e51, 2009.

[42] M. J. Barnes, H. Aksoylar, P. Krebs et al., "Loss of T cell and $\mathrm{B}$ cell quiescence precedes the onset of microbial floradependent wasting disease and intestinal inflammation in Gimap5-deficient mice," Journal of Immunology, vol. 184, no. 7, pp. 3743-3754, 2010.

[43] H. I. Aksoylar, K. Lampe, M. J. Barnes, D. R. Plas, and K. Hoebe, "Loss of immunological tolerance in Gimap5-deficient mice is associated with loss of foxo in CD4 + T cells," Journal of Immunology, vol. 188, no. 1, pp. 146-154, 2012.

[44] D. K. Podolsky, "Inflammatory bowel disease," The New England Journal of Medicine, vol. 347, no. 6, pp. 417-429, 2002.

[45] A. Izcue, J. L. Coombes, and F. Powrie, "Regulatory lymphocytes and intestinal inflammation," Annual Review of Immunology, vol. 27, no. 1, pp. 313-338, 2009.

[46] J. L. Round and S. K. Mazmanian, "The gut microbiota shapes intestinal immune responses during health and disease," Nature Reviews Immunology, vol. 9, no. 5, pp. 313-323, 2009.

[47] W. Strober, I. J. Fuss, and R. S. Blumberg, "The immunology of mucosal models of inflammation," Annual Review of Immunology, vol. 20, pp. 495-549, 2002.

[48] R. B. Sartor, "Microbial Influences in Inflammatory Bowel Diseases," Gastroenterology, vol. 134, no. 2, pp. 577-594, 2008.

[49] J. D. Taurog, J. A. Richardson, J. T. Croft et al., “The germfree state prevents development of gut and joint inflammatory disease in HLA-B27 transgenic rats," Journal of Experimental Medicine, vol. 180, no. 6, pp. 2359-2364, 1994.

[50] N. Iqbal, J. R. Oliver, F. H. Wagner, A. S. Lazenby, C. O. Elson, and C. T. Weaver, "T helper 1 and T helper 2 cells are pathogenic in an antigen-specific model of colitis," Journal of Experimental Medicine, vol. 195, no. 1, pp. 71-84, 2002.

[51] Y. Cong, S. L. Brandwein, R. P. McCabe et al., "CD4 ${ }^{+}$T cells reactive to enteric bacterial antigens in spontaneously colitic $\mathrm{C} 3 \mathrm{H} / \mathrm{HeJBir}$ mice: increased $\mathrm{T}$ helper cell type 1 response and ability to transfer disease," Journal of Experimental Medicine, vol. 187 , no. 6, pp. 855-864, 1998.

[52] S. R. Gill, M. Pop, R. T. DeBoy et al., "Metagenomic analysis of the human distal gut microbiome," Science, vol. 312, no. 5778, pp. 1355-1359, 2006.

[53] P. J. Turnbaugh, M. Hamady, T. Yatsunenko et al., "A core gut microbiome in obese and lean twins," Nature, vol. 457, no. 7228, pp. 480-484, 2009.

[54] D. A. Peterson, D. N. Frank, N. R. Pace, and J. I. Gordon, "Metagenomic approaches for defining the pathogenesis of inflammatory bowel diseases," Cell Host and Microbe, vol. 3, no. 6, pp. 417-427, 2008.

[55] S. Vaishnava, C. L. Behrendt, A. S. Ismail, L. Eckmann, and L. V. Hooper, "Paneth cells directly sense gut commensals and maintain homeostasis at the intestinal host-microbial interface," Proceedings of the National Academy of Sciences of the United States of America, vol. 105, no. 52, pp. 20858-20863, 2008.

[56] Y. Umesaki, H. Setoyama, S. Matsumoto, and Y. Okada, "Expansion of $\alpha \beta$ T-cell receptor-bearing intestinal intraepithelial lymphocytes after microbial colonization in germ-free mice and its independence from thymus," Immunology, vol. 79, no. 1, pp. 32-37, 1993.

[57] S. K. Mazmanian, J. L. Round, and D. L. Kasper, "A microbial symbiosis factor prevents intestinal inflammatory disease," Nature, vol. 453, no. 7195, pp. 620-625, 2008.

[58] K. Atarashi, T. Tanoue, K. Oshima et al., “Treg induction by a rationally selected mixture of Clostridia strains from the human microbiota," Nature, vol. 500, no. 7461, pp. 232-236, 2013.

[59] I. I. Ivanov, R. D. L. Frutos, N. Manel et al., "Specific microbiota direct the differentiation of IL-17-producing T-helper cells in the mucosa of the small intestine," Cell Host and Microbe, vol. 4, no. 4, pp. 337-349, 2008.

[60] I. I. Ivanov, K. Atarashi, N. Manel et al., "Induction of intestinal Th17 cells by segmented filamentous bacteria," Cell, vol. 139, no. 3, pp. 485-498, 2009.

[61] V. Gaboriau-Routhiau, S. Rakotobe, E. Lécuyer et al., "The key role of segmented filamentous bacteria in the coordinated maturation of gut helper T cell responses," Immunity, vol. 31, no. 4, pp. 677-689, 2009.

[62] D. N. Frank, A. L. St. Amand, R. A. Feldman, E. C. Boedeker, N. Harpaz, and N. R. Pace, "Molecular-phylogenetic characterization of microbial community imbalances in human inflammatory bowel diseases," Proceedings of the National Academy of Sciences of the United States of America, vol. 104, no. 34, pp. 13780-13785, 2007.

[63] R. J. Cahill, C. J. Foltz, J. G. Fox, C. A. Dangler, F. Powrie, and D. B. Schauer, "Inflammatory bowel disease: an immunitymediated condition triggered by bacterial infection with Helicobacter hepaticus," Infection and Immunity, vol. 65, no. 8, pp. 3126-3131, 1997.

[64] M. C. Kullberg, J. M. Ward, P. L. Gorelick et al., "Helicobacter hepaticus triggers colitis in specific-pathogen-free interleukin-10 (IL-10)-deficient mice through an IL-12-and gamma interferon- dependent mechanism," Infection and Immunity, vol. 66, no. 11, pp. 5157-5166, 1998.

[65] M. C. Kullberg, J. F. Andersen, P. L. Gorelick et al., "Induction of colitis by a CD4+ T cell clone specific for a bacterial epitope," Proceedings of the National Academy of Sciences of the United States of America, vol. 100, no. 26, pp. 15830-15835, 2003.

[66] A. Kaser and R. S. Blumberg, "Endoplasmic reticulum stress in the intestinal epithelium and inflammatory bowel disease," Seminars in Immunology, vol. 21, no. 3, pp. 156-163, 2009. 
[67] C. W. Lees, J. C. Barrett, M. Parkes, and J. Satsangi, "New IBD genetics: common pathways with other diseases," Gut, vol. 60, no. 12, pp. 1739-1753, 2011.

[68] A. Zhernakova, C. C. Van Diemen, and C. Wijmenga, "Detecting shared pathogenesis from the shared genetics of immunerelated diseases," Nature Reviews Genetics, vol. 10, no. 1, pp. 43$55,2009$.

[69] E.-O. Glocker, N. Frede, M. Perro et al., "Infant colitis-its in the genes," The Lancet, vol. 376, no. 9748, p. 1272, 2010.

[70] R. Kühn, J. Löhler, D. Rennick, K. Rajewsky, and W. Müller, "Interleukin-10-deficient mice develop chronic enterocolitis," Cell, vol. 75, no. 2, pp. 263-274, 1993.

[71] S. O. Lopez-Cubero, K. M. Sullivan, G. B. McDonald, and P. J. Stephen, "Course of Crohn's disease after allogeneic marrow transplantation," Gastroenterology, vol. 114, no. 3, pp. 433-606, 1998.

[72] K. W. Moore, R. De Waal Malefyt, R. L. Coffman, and A. O'Garra, "Interleukin-10 and the interleukin-10 receptor," Annual Review of Immunology, vol. 19, no. 1, pp. 683-765, 2001.

[73] C. L. Maynard and C. T. Weaver, "Diversity in the contribution of interleukin-10 to T-cell-mediated immune regulation," Immunological Reviews, vol. 226, no. 1, pp. 219-233, 2008.

[74] W. Ouyang, S. Rutz, N. K. Crellin, P. A. Valdez, and S. G. Hymowitz, "Regulation and functions of the IL-10 family of cytokines in inflammation and disease," Annual Review of Immunology, vol. 29, pp. 71-109, 2011.

[75] M. Murai, O. Turovskaya, G. Kim et al., "Interleukin 10 acts on regulatory $\mathrm{T}$ cells to maintain expression of the transcription factor Foxp3 and suppressive function in mice with colitis," Nature Immunology, vol. 10, no. 11, pp. 1178-1184, 2009.

[76] A. Roers, L. Siewe, E. Strittmatter et al., "T cell-specific inactivation of the interleukin 10 gene in mice results in enhanced $\mathrm{T}$ cell responses but normal innate responses to lipopolysaccharide or skin irritation," The Journal of Experimental Medicine, vol. 200, no. 10, pp. 1289-1297, 2004.

[77] Y. P. Rubtsov, J. P. Rasmussen, E. Y. Chi et al., "Regulatory T cellderived interleukin-10 limits inflammation at environmental interfaces," Immunity, vol. 28, no. 4, pp. 546-558, 2008.

[78] E. Zigmond, B. Bernshtein, G. Friedlander et al., "Macrophagerestricted interleukin-10 receptor deficiency, but not IL-10 deficiency, causes severe spontaneous colitis," Immunity, vol. 40, no. 5, pp. 720-733, 2014.

[79] R. J. Xavier and D. K. Podolsky, "Unravelling the pathogenesis of inflammatory bowel disease," Nature, vol. 448, no. 7152, pp. 427-434, 2007.

[80] L. V. Hooper and A. J. MacPherson, "Immune adaptations that maintain homeostasis with the intestinal microbiota," Nature Reviews Immunology, vol. 10, no. 3, pp. 159-169, 2010.

[81] C. Sorini and M. Falcone, "Shaping the (auto)immune response in the gut: the role of intestinal immune regulation in the prevention of type 1 diabetes," American Journal of Clinical and Experimental Immunology, vol. 2, no. 2, pp. 156-171, 2013.

[82] C. Abraham and J. H. Cho, "Inflammatory bowel disease," The New England Journal of Medicine, vol. 361, no. 21, pp. 20662078, 2009.

[83] C. L. Maynard and C. T. Weaver, "Intestinal effector T cells in health and disease," Immunity, vol. 31, no. 3, pp. 389-400, 2009.

[84] C. T. Weaver, C. O. Elson, L. A. Fouser, and J. K. Kolls, "The Th17 pathway and inflammatory diseases of the intestines, lungs, and skin," Annual Review of Pathology: Mechanisms of Disease, vol. 8, pp. 477-512, 2013.
[85] C. O. Elson, Y. Cong, C. T. Weaver et al., "Monoclonal antiinterleukin 23 reverses active colitis in a T cell-mediated model in mice," Gastroenterology, vol. 132, no. 7, pp. 2359-2370, 2007.

[86] A. Raza and M. T. Shata, "Letter: pathogenicity of Th17 cells may differ in ulcerative colitis compared with Crohn's disease," Alimentary Pharmacology and Therapeutics, vol. 36, no. 2, p. 204, 2012.

[87] Y. K. Lee, H. Turner, C. L. Maynard et al., "Late developmental plasticity in the T helper 17 lineage," Immunity, vol. 30, no. 1, pp. 92-107, 2009.

[88] M. Shale, C. Schiering, and F. Powrie, "CD4 ${ }^{+}$T-cell subsets in intestinal inflammation," Immunological Reviews, vol. 252, no. 1, pp. 164-182, 2013.

[89] E. K. Boden and S. B. Snapper, "Regulatory T cells in inflammatory bowel disease," Current Opinion in Gastroenterology, vol. 24, no. 6, pp. 733-741, 2008.

[90] D. A. A. Vignali, L. W. Collison, and C. J. Workman, "How regulatory T cells work," Nature Reviews Immunology, vol. 8, no. 7, pp. 523-532, 2008.

[91] E. M. Shevach, "Mechanisms of Foxp3+ T regulatory cellmediated suppression," Immunity, vol. 30, no. 5, pp. 636-645, 2009.

[92] J. H. Buckner, "Mechanisms of impaired regulation by CD4+ CD25+ FOXP3+ regulatory $\mathrm{T}$ cells in human autoimmune diseases," Nature Reviews Immunology, vol. 10, no. 12, pp. 849859, 2010.

[93] L. S. K. Walker, "Regulatory T cells overturned: the effectors fight back," Immunology, vol. 126, no. 4, pp. 466-474, 2009.

[94] E. Gambineri, T. R. Torgerson, and H. D. Ochs, "Immune dysregulation, polyendocrinopathy, enteropathy, and X-linked inheritance (IPEX), a syndrome of systemic autoimmunity caused by mutations of FOXP3, a critical regulator of T-cell homeostasis," Current Opinion in Rheumatology, vol. 15, no. 4, pp. 430-435, 2003.

[95] R. Bacchetta, L. Passerini, E. Gambineri et al., "Defective regulatory and effector $\mathrm{T}$ cell functions in patients with FOXP3 mutations," Journal of Clinical Investigation, vol. 116, no. 6, pp. 1713-1722, 2006.

[96] A. N. McMurchy, S. Di Nunzio, M. G. Roncarolo, R. Bacchetta, and M. K. Levings, "Molecular regulation of cellular immunity by FOXP3," Advances in Experimental Medicine and Biology, vol. 665, pp. 30-45, 2009.

[97] J. D. Fontenot, M. A. Gavin, and A. Y. Rudensky, "Foxp3 programs the development and function of $\mathrm{CD} 4^{+} \mathrm{CD} 25^{+}$regulatory T cells," Nature Immunology, vol. 4, no. 4, pp. 330-336, 2003.

[98] L. W. Collison, C. J. Workman, T. T. Kuo et al., "The inhibitory cytokine IL-35 contributes to regulatory T-cell function," Nature, vol. 450, no. 7169, pp. 566-569, 2007.

[99] J. E. Konkel and W. Chen, "Balancing acts: the role of TGF- $\beta$ in the mucosal immune system," Trends in Molecular Medicine, vol. 17, no. 11, pp. 668-676, 2011.

[100] S. Ramanathan and P. Poussier, "BB rat lyp mutation and type 1 diabetes," Immunological Reviews, vol. 184, pp. 161-171, 2001.

[101] L. Hornum, J. Rmer, and H. Markholst, "The diabetes-prone BB rat carries a frameshift mutation in Ian4, a positional candidate of Iddml," Diabetes, vol. 51, no. 6, pp. 1972-1979, 2002.

[102] A. J. MacMurray, D. H. Moralejo, A. E. Kwitek et al., "Lymphopenia in the $\mathrm{BB}$ rat model of type 1 diabetes is due to a mutation in a novel immune-associated nucleotide (Ian)related gene," Genome Research, vol. 12, no. 7, pp. 1029-1039, 2002 . 
[103] D. H. Moralejo, J. M. Fuller, E. A. Rutledge et al., "BB rat Gimap gene expression in sorted lymphoid T and B cells," Life Sciences, vol. 89, no. 19-20, pp. 748-754, 2011.

[104] M. Michalkiewicz, T. Michalkiewicz, R. A. Ettinger et al., "Transgenic rescue demonstrates involvement of the Ian5 gene in T cell development in the rat," Physiological Genomics, vol. 19, pp. 228-232, 2005.

[105] T. Nitta, M. Nasreen, T. Seike et al., "IAN family critically regulates survival and development of T lymphocytes," PLoS Biology, vol. 4, no. 4, article e103, 2006.

[106] T. Nitta and Y. Takahama, "The lymphocyte guard-IANs: regulation of lymphocyte survival by IAN/GIMAP family proteins," Trends in Immunology, vol. 28, no. 2, pp. 58-65, 2007.

[107] G. M. C. Poirier, G. Anderson, A. Huvar et al., "Immuneassociated nucleotide-1 (IAN-1) is a thymic selection marker and defines a novel gene family conserved in plants," Journal of Immunology, vol. 163, no. 9, pp. 4960-4969, 1999.

[108] L. Dahéron, T. Zenz, L. D. Siracusa, C. Brenner, and B. Calabretta, "Molecular cloning of Ian4: a BCR/ABL-induced gene that encodes an outer membrane mitochondrial protein with GTP-binding activity," Nucleic Acids Research, vol. 29, no. 6, pp. 1308-1316, 2001.

[109] O. Stamm, J. Krücken, H.-P. Schmitt-Wrede, W. P. M. Benten, and F. Wunderlich, "Human ortholog to mouse gene imap38 encoding an ER-localizable G-protein belongs to a gene family clustered on chromosome 7q32-36," Gene, vol. 282, no. 1-2, pp. 159-167, 2002.

[110] C. Plamondon, V. Kottis, C. Brideau, M.-D. Metroz-Dayer, and P. Poussier, "Abnormal thymocyte maturation in spontaneously diabetic BB rats involves the deletion of CD4-8+ cells," Journal of Immunology, vol. 144, no. 3, pp. 923-928, 1990.

[111] D. Schwefel, C. Fröhlich, J. Eichhorst et al., "Structural basis of oligomerization in septin-like GTPase of immunity-associated protein 2 (GIMAP2)," Proceedings of the National Academy of Sciences of the United States of America, vol. 107, no. 47, pp. 20299-20304, 2010.

[112] D. Schwefel, B. S. Arasu, S. F. Marino et al., "Structural insights into the mechanism of GTPase activation in the GIMAP family," Structure, vol. 21, no. 4, pp. 550-559, 2013.

[113] V. W. Y. Wong, A. E. Saunders, A. Hutchings et al., "The autoimmunity-related GIMAP5 GTPase is a lysosomeassociated protein," Self/Nonself-Immune Recognition and Signaling, vol. 1, no. 3, pp. 259-268, 2010.

[114] J. H. Shin, M. Janer, B. McNeney et al., "IA-2 autoantibodies in incident type I diabetes patients are associated with a polyadenylation signal polymorphism in GIMAP5," Genes \& Immunity, vol. 8, no. 6, pp. 503-512, 2007.

[115] A. Hellquist, M. Zucchelli, K. Kivinen et al., "The human GIMAP5 gene has a common polyadenylation polymorphism increasing risk to systemic lupus erythematosus," Journal of Medical Genetics, vol. 44, no. 5, pp. 314-321, 2007.

[116] M. K. Lim, D. H. Sheen, S. A. Kim et al., "IAN5 polymorphisms are associated with systemic lupus erythematosus," Lupus, vol. 18, no. 12, pp. 1045-1052, 2009.

[117] P. Jailwala, J. Waukau, S. Glisic et al., "Apoptosis of CD4+CD25high $\mathrm{T}$ cells in type 1 diabetes may be partially mediated by IL-2 deprivation," PLoS ONE, vol. 4, no. 8, Article ID e6527, 2009.

[118] H. Groen, F. A. Klatter, N. H. C. Brons, G. Mesander, P. Nieuwenhuis, and J. Kampinga, "Abnormal thymocyte subset distribution and differential reduction of $\mathrm{CD}^{+}$and $\mathrm{CD} 8^{+} \mathrm{T}$ cell subsets during peripheral maturation in diabetes-prone biobreeding rats," Journal of Immunology, vol. 156, no. 3, pp. 1269-1275, 1996.

[119] H. H. Zadeh, D. L. Greiner, D. Y. Wu, F. Tausche, and I. Goldschneider, "Abnormalities in the export and fate of recent thymic emigrants in diabetes-prone BB/W rats," Autoimmunity, vol. 24, no. 1, pp. 35-46, 1996.

[120] R. D. Schulteis, H. Chu, X. Dai et al., "Impaired survival of peripheral $\mathrm{T}$ cells, disrupted NK/NKT cell development, and liver failure in mice lacking Gimap5," Blood, vol. 112, no. 13, pp. 4905-4914, 2008.

[121] S. Cashman, K. Lampe, R. Sheridan, and K. Hoebe, "An ENU mutagenesis approach to dissect "self"-induced immune responses: Unraveling the genetic footprint of immunosurveillance," OncoImmunology, vol. 1, no. 6, pp. 856-862, 2012.

[122] J. Satsangi, M. S. Silverberg, S. Vermeire, and J.-F. Colombel, "The Montreal classification of inflammatory bowel disease: controversies, consensus, and implications," Gut, vol. 55, no. 6, pp. 749-753, 2006.

[123] G. Vernier-Massouille, M. Balde, J. Salleron et al., "Natural history of pediatric crohn's disease: a population-based cohort study," Gastroenterology, vol. 135, no. 4, pp. 1106-1113, 2008.

[124] C. D. Surh and J. Sprent, "Homeostasis of naive and memory T cells," Immunity, vol. 29, no. 6, pp. 848-862, 2008.

[125] F. Powrie and M. W. Leach, "Genetic and spontaneous models of inflammatory bowel disease in rodents: evidence for abnormalities in mucosal immune regulation," Therapeutic Immunology, vol. 2, no. 2, pp. 115-123, 1995.

[126] M. J. Anderson, C. S. Viars, S. Czekay, W. K. Cavenee, and K. C. Arden, "Cloning and characterization of three human forkhead genes that comprise an FKHR-like gene subfamily," Genomics, vol. 47, no. 2, pp. 187-199, 1998.

[127] W. H. Biggs III, W. K. Cavenee, and K. C. Arden, "Identification and characterization of members of the FKHR (FOX O) subclass of winged-helix transcription factors in the mouse," Mammalian Genome, vol. 12, no. 6, pp. 416-425, 2001.

[128] Y. M. Kerdiles, E. L. Stone, D. L. Beisner et al., "Foxo transcription factors control regulatory $\mathrm{T}$ cell development and function," Immunity, vol. 33, no. 6, pp. 890-904, 2010.

[129] W. Ouyang, O. Beckett, Q. Ma, J.-H. Paik, R. A. Depinho, and M. $\mathrm{O}$. Li, "Foxo proteins cooperatively control the differentiation of Foxp $3^{+}$regulatory T cells," Nature Immunology, vol. 11, no. 7, pp. 618-627, 2010.

[130] R. R. Gomis, C. Alarcón, W. He et al., "A FoxO-Smad synexpression group in human keratinocytes," Proceedings of the National Academy of Sciences of the United States of America, vol. 103, no. 34, pp. 12747-12752, 2006.

[131] J. Seoane, H.-V. Le, L. Shen, S. A. Anderson, and J. Massagué, "Integration of smad and forkhead pathways in the control of neuroepithelial and glioblastoma cell proliferation," Cell, vol. 117, no. 2, pp. 211-223, 2004.

[132] S. M. Hedrick, R. H. Michelini, A. L. Doedens, A. W. Goldrath, and E. L. Stone, "FOXO transcription factors throughout T cell biology," Nature Reviews Immunology, vol. 12, no. 9, pp. 649-661, 2012.

[133] B. M. Fournier and C. A. Parkos, "The role of neutrophils during intestinal inflammation," Mucosal Immunology, vol. 5, no. 4, pp. 354-366, 2012. 


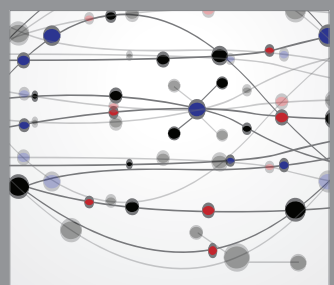

The Scientific World Journal
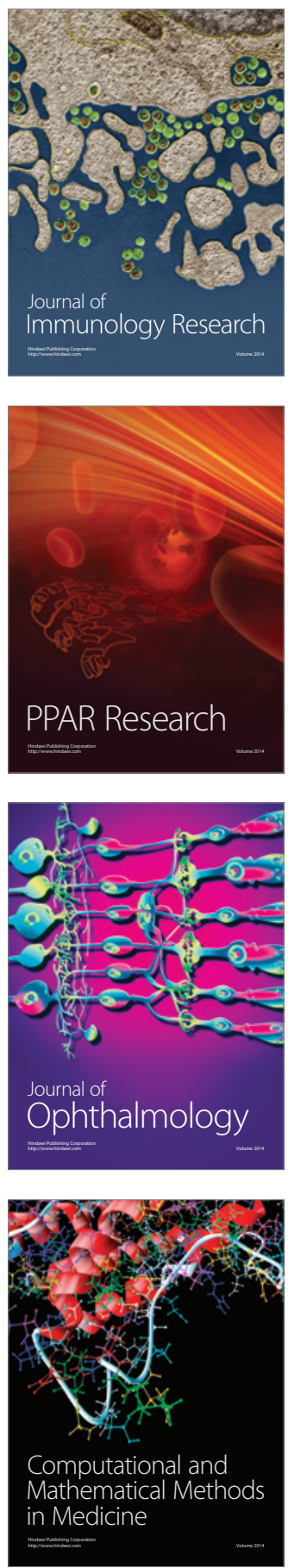

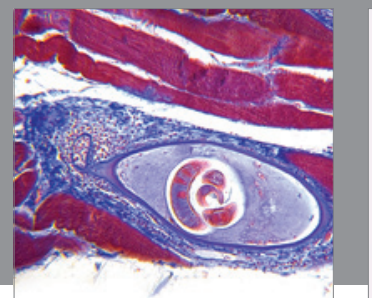

Gastroenterology

Research and Practice
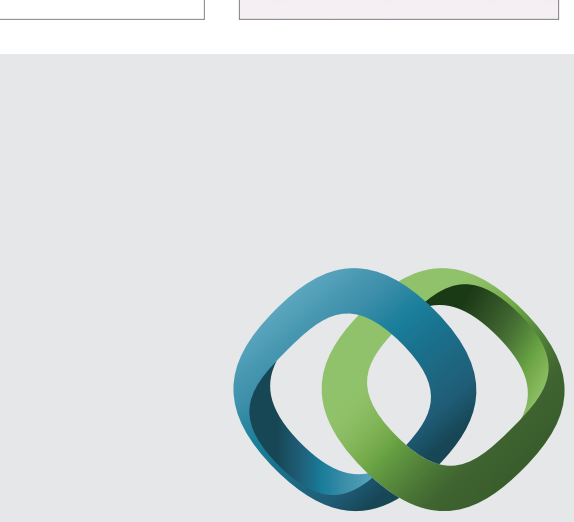

\section{Hindawi}

Submit your manuscripts at

http://www.hindawi.com
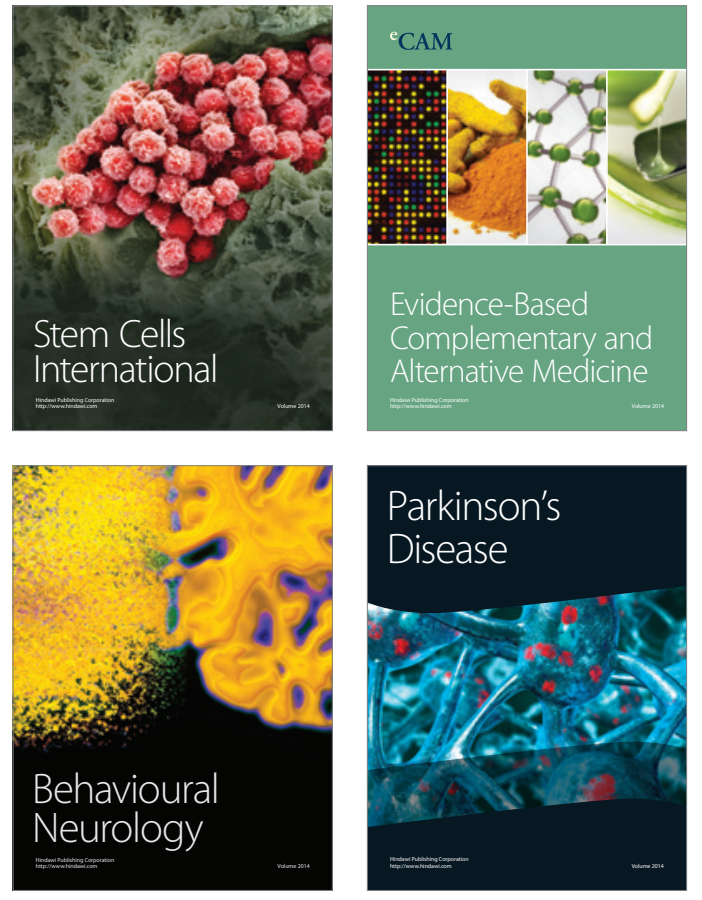
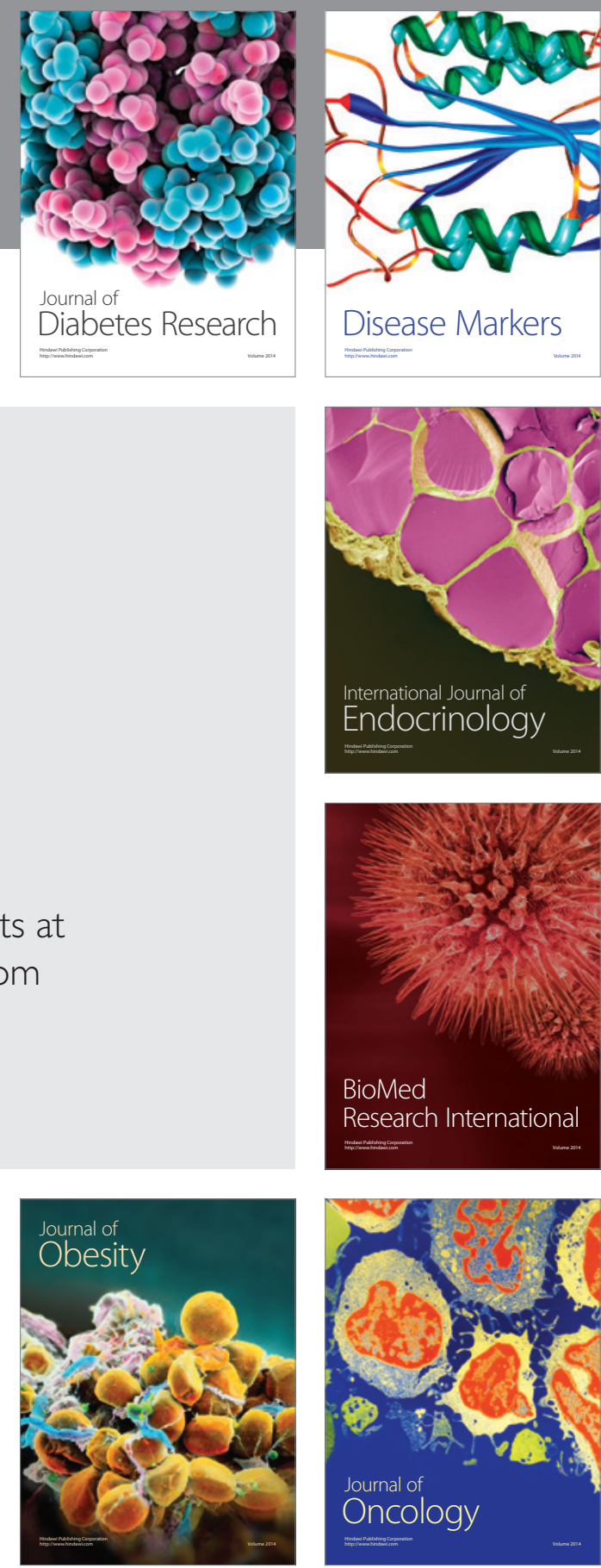

Disease Markers
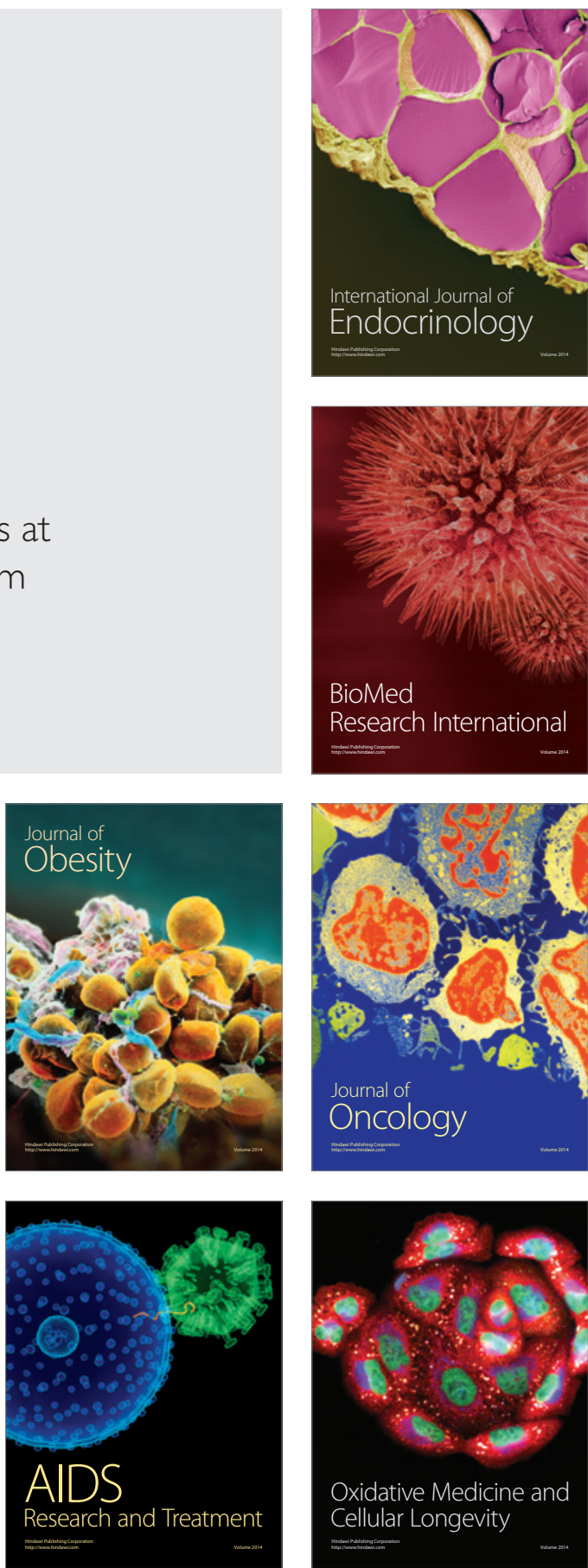